\title{
Cultivation of College Students' English Communication Competence
}

\section{Dongmei Sheng}

\author{
Foreign Language Department, Jilin Business and Technology College, Changchun, China \\ 455635403@qq.com
}

Keywords: Communication; Strategy; Strategic competence; Training mode

\begin{abstract}
The aim of this study is to promote students' communication competence. It is thought to be the essential task in foreign language teaching. This paper presents communicative strategic competence training focusing on implicit training and most communication strategies. The writer describes the advantage of integrating four aspects into the English movies. The four aspects are the speech, culture, word learning and teaching method. The writer also further explores the method for the selection of materials for the English film and the strategies in oral English teaching using English movies. The result suggests that the teaching strategies can quickly improve the English communication ability of college students.
\end{abstract}

\section{Introduction}

With the continuous development of information technology, English movie as a kind of comprehensive art, is not only entertaining, but plays a considerable role in oral English teaching. A growing number of exchanging opportunities have increased the demand for oral communication ability. Because of a lack of real language environment, the cultivation of oral English ability faces a lot of trouble. Lacking the opportunity of speaking English and listening to real English, most of the students' English becomes into the dumb English. When facing real communication, at ordinary times the written knowledge is no use. The traditional college English teaching considered the teacher as the center, who gives priority to language knowledge. Teacher is the main body of teaching process and the dominator of content and method. Examination-oriented education and the national university English test, influence the college English teaching. Teachers should focus on the improvement of listening comprehension, vocabulary enlargement and discourse comprehension, translation skills. The cultivation of reading and writing can be strengthening. The improvement of oral English ability has been put in the optional position, let alone the cultivation of oral communication strategy. This opinion misleads students to think that oral English is not so important. Then they do not invest time and effort. Since: students' oral English is not fluent, pragmatic mistakes frequently appear. Oral communication ability is influenced by the following factors: the basic knowledge of voice, relaxed spirit when speaking and the way of thinking. These problems have been plagued by English educators. The advantages of English movies can help college students solve the problems existing in the oral training.

\section{Advantage of Pronunciation}

In the process of watching English movies, a lot of students have such confusion that they usually understand the news they listen to, but they can't understand when watching English movies. The phenomenon is related to the language characteristics of English films. The language in English film is spoken in language style. We usually contact the written language more and it is very different in the sentence structure and the film language. The characteristics of English film language are just for students to provide high-quality oral material. The English version of the film provides the students with more opportunities to contact with the real English. The pronunciation of English books is thought as the standard of English pronunciation for students. But there is a certain gap between the voice and the real life. For example, a weak voice, tone, ellipsis is a very common phenomenon in oral communication. But we can not learn all about it in the book. Some students can get a high score in English test, but they can not understand English in the real communication. 
The English original film has made up for this deficiency. English movies from all aspects of life in Britain or the United States are real and authentic. It contains people's dialogue of different ages and different social strata. Dialogue between the characters in the film offers a chance to touch the real life in English.

\section{Advantage of Culture}

Language is the carrier of culture. The improvement of English communicative competence depends on the understanding of cultural tradition of the target language. English film offers a chance to experience the culture of the British and American countries. English film is created based on the real life of all levels. For example, the film "Gone with the Wind" is this type. While enjoying the movies, the students also learn the history of the British and American countries and increase the knowledge of the cultural background. Language learning is actually a culture of learning. Scenes of life in English movies show the western social customs of the west and the most common meal in the life. The general conversation in the textbooks will be exposed to ordering in the restaurant. The textbooks would not teach this. We can learn more from the English movies. The following sentences are the examples. "I'd like the chef's salad, please, with the oil and vinegar on the side, and the apple pie. I'd like the pie heated, and I want the ice cream on the side. And I'd like strawberry instead of vanilla, if you have it. If not, then no ice cream, just whipped cream, but only if it's real. If it's out of a can, then nothing.

\section{Advantage of Teaching Method}

The traditional teaching way is confined to books and the blackboard. The longer the studying time is, the more bored you are. The application of multimedia technology in English class makes English movie more widely used in English teaching. English movies integrate the image and the sound and form the sound and the image into a piece of complete information. It effectively combines visual stimulation and auditory stimulation, which can not be made by other learning methods. If it cooperates with other teaching activities, you'll learn English with happiness. Practice shows that language learning is closely related to emotional factors. In foreign language teaching, building a classroom atmosphere is helpful for students to master the grammar and the vocabulary. If students study in a constrained learning atmosphere, they will inevitably generate a psychological disorder and affect their subjective initiative, which makes the learning effect greatly reduced. Therefore, English teachers should minimize the negative factors that affect emotions as much as they can. The entertainment functions of English movie, which makes the classroom activities relaxing and happy, is bound to eliminate students' psychological disorder, and makes students, improve the learning efficiency in their best condition.

Language learning need input internalization and output. Watching English movies is part of inputting language. The teachers must not ignore the part of output. Watching English movie and television, writing English study notes and the expressing valuable sentences as possible are the nest way. In this way the students can combine listening and speaking effectively. Secondly, on the basis of understanding the film teachers can use multimedia courseware and use a variety of teaching methods to organize the speaking activities. Try to create opportunities for spoken English in class. Two kinds of performances are imitation and free play. The movie "the lion king" can be used to organize the students to imitate the dialogue. By imitating the students practice pronunciation and intonation. Free play means letting students adapt the plot or add the ending, and then organize students to play the performance. This method can also strengthen the content of this film, the leading character, dialogue, performers, clothing props, scene layout. As the main body of the discussion, the advantages of film teaching can be used. Group discussion also can be used by the students. On the basis of appreciation of the film, after the discussion in small groups, oral report was designed. Domestic English language environment can be watched in English films and can create an "immersive" English language environment. From the cognitive law level, the combined image and words are consistent with the understanding of the laws and rules of learning a 
foreign language. In modern foreign language teaching, attention and emphasis on English film are put into classroom and teaching is conforming to the requirements.

English teachers should adopt correct learning methods. When watching the film, you can hide the subtitles and focus their attention on the content. It is recommended to spend one or two hours a day, at least four times a day. At the first times the task is to understand the plot only. The students need to understand how much they could understand without read the Chinese sentences; the second times the students need to watch as much as possible. The third time students have to watch the dialogue and repeatedly listen to the conversation. It is convenient to use the machine to practice dictation. The effect is good according to the statistics if you do dictation lines better.

\section{Conclusion}

In the process of cultivating students' oral communicative competence, the film teaching has broken the limitation of traditional foreign language teaching method and has highlighted the unique advantages of English film. Enjoying English movies not only improves the ability of oral communication, but also has a further understanding of the political, economic, technological and historical periods of foreign countries, and enhances the study of language and culture. This new type of training methods will play the advantages of English movies and comprehensively improve the ability of spoken English.

\section{References}

[1] Bachman, L.F. Fundamental Consideration in Language Testing Oxford: (Oxford University Press, 1990)

[2] Bachman, L...F., \&Palmer, A.S. Language Testing in Practice (Oxford: Oxford University Press, 1996)

[3] Bialystok E. Strategies in Interlingua Communication (London and New York: Longman, 1983)

[4] Cohen, A., Weaver, S.J. \&Li, T.Y. The Impact of Strategies-based Instruction on Speaking a Foreign Language. ( Beijing: Foreign Language Teaching and Research Press. 2000)

[5] David Hoopes. Intercultural communication concepts and the psychology of intercultural experience in Multicultural Education, Vol.67 (1981) No7. p.56

[6] Dornyei, Z. TESOL Quarterly, Vol.35 (2005) No8. p.23

[7] Tarone, E... Applied Linguistics, Vol.21 (1983) No5. p.34.

[8] Widdowson H G Applied Linguistics, Vol.21 (1989) No9. p.45.

[9] Willems, G. System, Vol.21 (1987) No6. p.14.

[10]Tarone, E. Applied Linguistics, Vol.21 (1983) No7. p.24. 